\title{
AKNE VULGARIS DEWASA : ETIOLOGI, PATOGENESIS DAN TATALAKSANA TERKINI
}

\author{
Astrid Teresa \\ Fakultas Kedokteran Universitas Palangka Raya
}

\begin{abstract}
ABSTRAK
Akne vulgaris (AV) bukan lagi menjadi masalah kulit yang sering dijumpai pada remaja namun juga menjadi masalah yang sering ditemukan di usia dewasa. Dibandingkan dengan AV remaja, AV dewasa memiliki predileksi dan jenis lesi yang berbeda pula. Berbagai faktor penyebab munculnya AV dewasa yaitu adanya pengaruh hormonal, sensitifitas reseptor androgen mempengaruhi produksi sebum pada pasien AV. Tinjauan pustaka ini akan membahas mengenai etiologi, patogenesis, gambaran klinis dan tatalaksana AV terkini. Dengan mengetahui penyebab munculnya akne pada dewasa dan proses perjalanan penyakitnya diharapkan terapi yang tepat dapat diberikan agar menghasilkan perbaikan yang optimal.
\end{abstract}

Kata kunci: akne vulgaris dewasa, hormon, sebum.

\section{ABSTRACT}

Acne Vulgaris (AV) not only affect adolescence but also epidemiologic study shown $A V$ increases in adult. Compared to adolescence $A V$, adult $A V$ has different site of predilection and types of lesion. Some causal factors of adult $A V$ are hypothesized such as hormonal impact and sensitivity of androgen reseptor influencing sebum production of patients' AV. This review explains about etiology, pathogensis, clinical morphology and appropriate AV treatment. By understanding etiology of adult acne and process of acne development, an appropriate treatment for achieving optimal recovery could be given.

Keywords: adult acne vulgaris, hormone, sebum 


\section{PENDAHULUAN}

Akne vulgaris (AV) didefinisikan sebagai penyakit kulit akibat inflamasi kronik unit pilosebasea yang terdiri atas lesi non inflamasi seperti komedo terbuka dan komedo tertutup serta lesi inflamasi berupa papul, pustul, dan nodul. ${ }^{1}$ Sebanyak $85 \%$ AV didapatkan pada remaja namun AV juga ditemukan pada $20-40 \%$ usia dewasa dan didapatkan paling banyak pada perempuan. ${ }^{2,3}$ AV dewasa dibagi menjadi dua jenis yaitu, AV menetap (AVM) yaitu lesi akne yang berlanjut dari usia remaja hingga dewasa dan AV awitan lambat yaitu AV yang muncul saat usia dewasa. Menurut literatur AV dewasa adalah AV yang dijumpai pada usia 25 tahun. ${ }^{4}$ AVM lebih banyak dijumpai dibandingan dengan AV awitan lambat. ${ }^{5}$ Di poliklinik Ilmu Kesehatan Kulit dan Kelamin (IKKK) RS dr. Cipto Mangunkusumo (RSCM) persentase kunjungan baru pasien AV perempuan dewasa pada tahun 2014 sebanyak 4.3\%, tahun 2015 sebanyak $4.72 \%$ dan tahun 2016 sebanyak $4.67 \%{ }^{6}$

AV dewasa memiliki dampak terhadap kualitas hidup yang lebih buruk bila dibandingkan dengan AV remaja. ${ }^{6,7}$ Pemicu AV dewasa diduga disebabkan oleh faktor genetik dan hormonal.

\section{ETIOLOGI}

Penyebab pasti terjadinya AV dewasa belum dapat dipastikan. Namun beberapa faktor yang berperan dalam munculnya AV antara lain akibat hipersekresi hormon androgen, meningkatnya sekresi sebum, bertambahnya jumlah Propionibacterium acnes, hiperkeratosis yang membentuk mikrokomedo, dan meningkatnya respon inflamasi. $^{8}$
Pengaruh genetik terhadap munculnya AV dibuktikan dengan ditemukannya 50\% pasien AV memiliki keluarga dengan riwayat AV. Kebiasaan merokok atau paparan asap rokok juga meningkatkan kejadian AV dan keparahannya. ${ }^{9}$ Paparan sinar matahari juga menjadi penyebab munculnya AV karena radiasi sinar ultra violet akan menyebabkan peroksidasi yang komedogenik dan reaksi inflamasi.

- Hormon

Pada umumnya AV muncul ketika adrenarche yaitu masa pubertas saat terjadi lonjakan produksi hormon adrenal yang pada akhirnya akan menstimulasi perkembangan kelenjar sebasea dan produksi sebum. Pada individu yang rentan, berbagai penyakit akibat dermatosis androgenik dapat ditemukan seperti alopesia androgenik, seborea, hirsutisme, dan AV. ${ }^{10,11}$ Peran androgen dalam patogenesis AV dewasa masih diperdebatkan. Pemicu AV dewasa bukan hanya produksi sistemik namun juga produksi lokal hormon androgen. ${ }^{11}$

- Bakteri

Dalam praktik sehari-hari sering ditemukan penggunaan antibiotik untuk AV dalam durasi waktu yang lebih lama daripada yang dianjurkan. Penggunaan antibiotik yang berkepanjangan akan menyebabkan $P$. acnes menjadi resisten terhadap antibiotik standar untuk terapi AV. ${ }^{12,13}$ Seribu pasien yang berkunjung ke dokter spesialis di Harrogate $80 \%$ resisten terhadap eritromisin atau klindamisin atau keduanya dan 20\% resisten terhadap tetrasiklin. ${ }^{14}$

- Kosmetik 
Sembilan puluh lima persen kasus AV disebabkan oleh kosmetik dan Kligman menyebutkan acne cosmetic memiliki gambaran berupa AVR menetap pada usia dewasa. ${ }^{15}$ Durasi penggunaan kosmetik tidak berhubungan bermakna dengan keparahan AV dan penghentian penggunaan kosmetik tidak menimbulkan perbaikan AV. ${ }^{16}$ Peran kosmetik secara langsung pada AV tidak ditemukan namun kosmetik dapat memicu folikel untuk membentuk akne. ${ }^{17}$

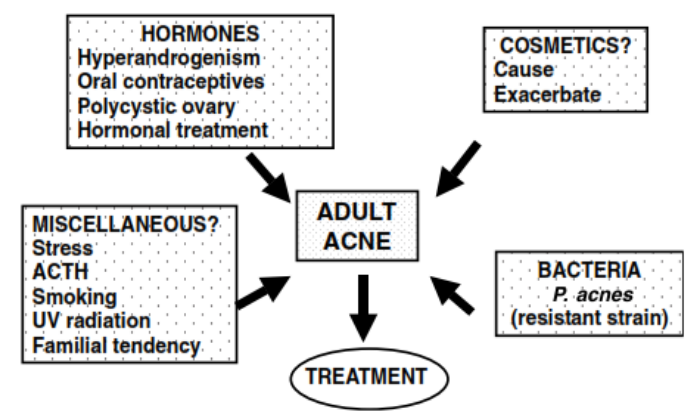

Gambar 1. Kemungkinan Penyebab AV

Dewasa $^{18}$

\section{PATOGENESIS}

Patogenesis AV memiliki 4 faktor penyebab yaitu (1) folikel epidermis yang mengalami proliferasi berlebih, (2) hipersekresi sebum, (3) Inflamasi, dan (4) keberadaan $P$. acnes. ${ }^{19,20}$

1. Folikel epidermis yang mengalami proliferasi berlebih

Hiperproliferasi folikel epidermis akan menyebabkan epitel folikel rambut mengalami hiperkeratosis sehingga terjadi kohesi antarkeratinosit. Kohesi ini akan menyebabkan ostium folikel tersumbat sehingga meimbulkan dilatasi folikel dan terbentuknya komedo. Peningkatan produksi androgen, rendahnya asam linoleat dan meningkatnya aktivitas interleukin (IL)-1a menjadi faktor penyebab hiperproliferasi keratinosit. ${ }^{19,20}$

Dihidrotestosteron (DHT) adalah androgen poten yang berperan dalam patogenesis AV. Konversi DHEAS menjadi DHT memerlukan enzim 17 $\beta$-hidroksisteroid dehidrogenase (17 $\beta$-HSD) dan $5 \alpha$ reduktase. ${ }^{21}$ DHT akan menyebabkan proliferasi keratinosit folikular pada seseorang yang sensitif terhadap androgen sehingga akne berkembang.

Rendahnya produksi asam linoleat yang merupakan asam lemak esensial pada kulit penderita AV akan menginduksi hiperproliferasi keratinosit folikular dan produksi sitokin proinflamasi. Terdapat pula teori yang menjelaskan bahwa asam linoleat diproduksi normal pada kulit penderita AV namun tingginya produksi sebum menyebabkan asam lemak terdilusi. ${ }^{22}$ IL-1 menunjukkan perannya dalam pembentukan mikrokomedo dengan meningkatkan proliferasi keratinosit. Adanya antagonis reseptor IL-1 akan menghambat terbentuknya mikrokomedo. ${ }^{23}$

\section{Hipersekresi sebum}

Kulit penderita AV akan memproduksi sebum dalam jumlah yang lebih besar dibandingkan kulit tanpa akne dengan komposisi sebum yang sama. Trigliserida adalah komponen penting dari sebum yang dihasilkan. P. acnes yang merupakan flora normal kulit berupa bakteri gram positif anaerob akan memecah trigliserida menjadi asam lemak bebas. Asam lemak bebas digunakan oleh bakteri ini untuk membentuk kolonisasi yang lebih banyak sehingga inflamasi terjadi dan komedo terbentuk. ${ }^{20}$

3. Inflamasi dan keberadaan P. acnes

Reaksi inflamasi yang disebabkan oleh keberadaan $P$. acnes melalui beberapa mekanisme. Pertama, adanya antigen di 
dinding $P$. acnes menyebabkan munculnya antibodi terhadap bakteri ini. ${ }^{16}$ Kedua, lipase, protease, hialuronidase dan faktor kemotaktik berperan menjadi penyebab munculnya rekasi hipersensitivitas tipe lambat. ${ }^{24}$ Melalui ikatannya dengan Toll-like receptor 2 (TLR-2) pada monosit dan sel polimorfonukleus (PMN) yang mengelilingi folikel sebasea akan menstimulasi produksi sitokin. $^{25}$

Peran androgen dalam produksi sebum melalui aksinya pada sebosit. Kadar androgen pasien AV lebih tinggi (meskipun dalam rentang normal) dibandingkan kelompok kontrol. ${ }^{26}$ Lima alfa reduktase akan mengonversi testosteron menjadi DHT di daerah kulit yang rentan berjerawat seperti wajah, dada dan punggung.

Akumulasi dari keratin dan sebum akan menjadikan mikrokomedo menjadi makrokomedo. Semakin besar komedo akan menyebabkan rupturnya dinding folikel. Keluarnya sebum, keratin dan bakteri ke dermis menimbulkan reaksi inflamasi cepat. Dalam 24 jam pertama limfosit akan mendominasi dan pada hari selanjutnya neutrofil lebih banyak ditemukan. ${ }^{27}$

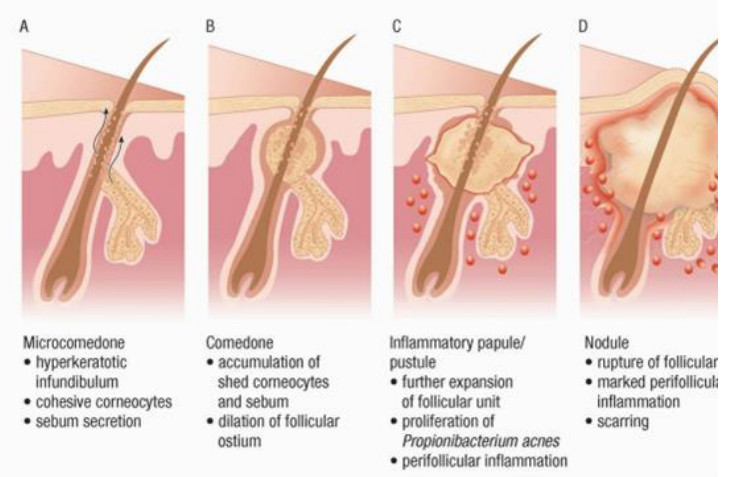

Gambar 2. Patogenesis akne ${ }^{16}$

\section{Androgen dan Akne}

Dehidroepiandrosteron

(33-hydroxy-5-

androsten-17-one, DHEA) disekresikan oleh korteks adrenal, traktus gastrointestinal, gonad dan otak. Bentuk metabolit sulfatnya adalah DHEAS yang merupakan hormon steroid yang paling banyak bersirkulasi di dalam tubuh. ${ }^{28}$ DHEA dan DHEAS menyediakan $50 \%$ androgen laki-laki dan $75 \%$ estrogen perempuan premenopause. ${ }^{29}$ Kadar DHEAS/DHEAS akan menurun dengan bertambahnya usia. ${ }^{30}$

Androgen memiliki peranan terhadap perkembangan dan pengaturan kelenjar sebasea dalam sekresi sebum pada laki-laki maupun perempuan. Kadar sebum yang disekresikan saat lahir sama dengan saat dewasa. Ketika tahap prepubertas kelenjar sebasea mengalami regresi namun ketika mencapai pubertas kelenjar ini membesar dengan cepat dan menyekresikan banyak sebum. Produksi sebum tidak berubah sampai mencapai usia 60 tahun. Saat usia tua kelenjar sebasea mengalami penurunan turn over sel sehingga kelenjar ini menjadi lebih besar.

Korteks adrenal menghasilkan tiga steroid yaitu DHEA, androstenedion (A4) dan testosteron (T). DHEA berasal dari pemecahan kolesterol menjadi pregnenolon dan mengalami hidroksilasi menjadi 17hidroksipregnenolon dengan bantuan CYP450c7 kemudian sisi rantai C17 dipecah sehingga terbentuk DHEA. DHEA akan dibebaskan dan mengalami konversi menjadi A4 dengan bantuan $3 \beta$ hydroxysteroid dehydrogenase ( $3 \beta$-HSD). Sebagian besar DHEA disulfatasi oleh DHEAsulfotransferase (DHEA-ST) menjadi DHEAS yang banyak di dalam sirkulasi. ${ }^{31}$

Kadar DHEA/DHEAS memuncak saat usia sekitar 20 tahun dan menurun seiring dengan bertambahnya usia. Kadar DHEA dan DHEAS laki-laki dan perempuan dapat dilihat pada tabel 1 dan 2, Produksi DHEAS diatur $60 \%$ oleh genotip pada lokus yang dekat dengan gen berikut: BCL2L11, 
Kadar DHEA meningkat pada pagi hari sesuai dengan irama sirkardian sekresi diproduksi di ovarium dan hampir semua DHEAS diproduksi oleh korteks adrenal sehingga DHEAS dapat menggambarkan produksi androgen prekursor adrenal dibandingkan hormone lainnya. DHEAS diproduksi dengan cepat, memiliki clearance rate metabolik yang rendah, kadarnya tinggi di dalam darah dan fluktuasi diurnalnya rendah. ${ }^{34}$

Tabel 1. Kadar DHEA ${ }^{11,35}$

\begin{tabular}{|c|c|c|c|}
\hline & $\begin{array}{c}\text { Jenis } \\
\text { Kelamin }\end{array}$ & $\begin{array}{c}\text { Rentang } \\
\text { Usia } \\
\text { (tahun) }\end{array}$ & $\begin{array}{c}\text { Rentang } \\
\text { DHEA } \\
(n g / L)\end{array}$ \\
\hline DHEA & Laki-laki & $\begin{array}{c}6-24 \\
\text { bulan } \\
2-3 \\
4-5 \\
6-7 \\
7-9 \\
10-11 \\
14-15 \\
16-17 \\
18-40 \\
40-67\end{array}$ & $\begin{array}{c}<2.500 \\
<630 \\
60-1,930 \\
60-1.930 \\
100- \\
2,080 \\
320- \\
3,080 \\
930- \\
6,040 \\
1,170- \\
6,520 \\
1,330- \\
7,780 \\
630- \\
4,700\end{array}$ \\
\hline & Perempuan & $\begin{array}{c}6-24 \\
\text { bulan } \\
2-3 \\
4-5 \\
6-7 \\
7-9 \\
10-11 \\
12-13 \\
14-15 \\
16-17 \\
18-40 \\
40-67\end{array}$ & $\begin{array}{c}<1,990 \\
<630 \\
<1,030 \\
120- \\
1,520 \\
140- \\
2,350 \\
430- \\
3,780 \\
890- \\
6,210 \\
1,220- \\
7,010\end{array}$ \\
\hline
\end{tabular}

Tabel 2. Kadar DHEAS ${ }^{11,35}$

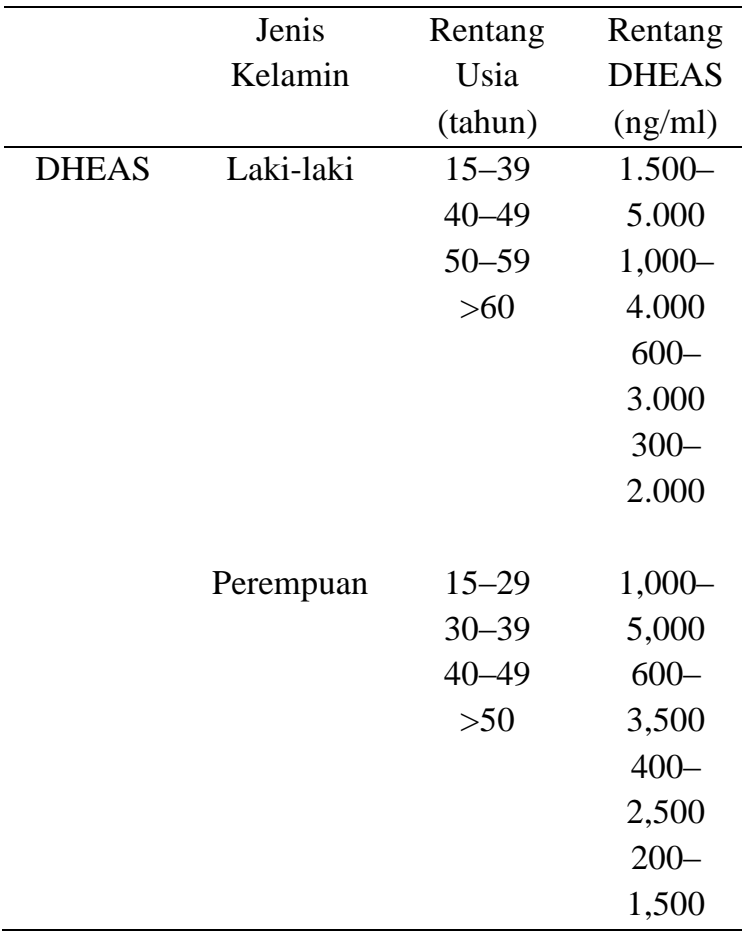

\section{Androgen pada kulit}

DHEA akan dikonversikan menjadi testosteron dan DHT di gonad, hati, dan jaringan perifer. Di kulit DHEA akan dikonversi menjadi androstenedion oleh $3 \beta$ HSD. Androstenedion kemudian dikonversi menjadi testosteron dengan bantuan 17 $\beta$ HSD yang bersifat reversibel dan menjadi DHT oleh $5 \alpha$-reduktase atau menjadi estrogen yang kurang poten dengan bantuan enzim aromatase. ${ }^{36,37}$

Reseptor androgen yang terdapat di dasar kelenjar sebasea dan lapisan luar keratinosit folikel rambut akan berinteraksi dengan testosteron dan dehidrotestosteron. DHT 510 kali lebih poten berinteraksi dengan resptor androgen dibandingkan testosteron. 
Namun baik DHT maupun testosteron tetap berperan dalam produksi sebum.

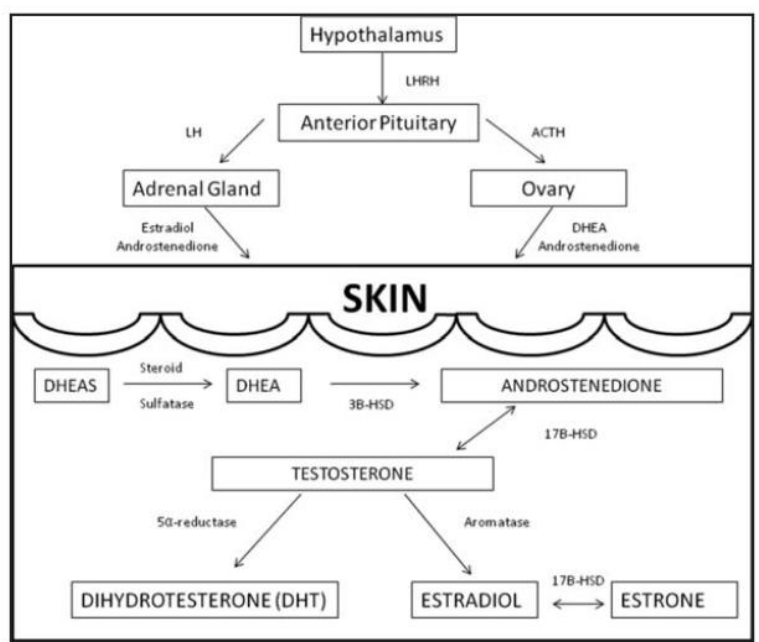

Gambar 3 Jalur metabolisme androgen ${ }^{38}$

Pada pasien AV dewasa ditemukan kadar serum DHEAS, testosteron dan DHT berada pada rentang normal hingga tinggi. Selain itu androgen juga diproduksi secara lokal di kulit sehingga menimbulkan hubungan intrakrin antara androgen dan reseptor androgen di kelenjar sebasea. Reseptor androgen pada kelenjar sebasea lebih sensitif terhadap androgen pada kulit pasien yang berjerawat. ${ }^{39}$ Penelitian yang dilakukan Cappel dkk. pada subyek perempuan usia 18-45 tahun, didapatkan hasil bahwa kadar DHEAS dan DHT berhubungan bermakna dengan jumlah total lesi akne, jumlah komedo dan jumlah lesi inflamasi. Hormon testosteron berhubungan bermakna dengan jumlah lesi inflamasi namun tidak berkaitan dengan jumlah lesi akne dan komedo. Pada subyek laki-laki kadar DHEAS berhubungan dengan jumlah total lesi akne dan komedo namun tidak berhubungan dengan jumlah lesi inflamasi. ${ }^{40}$ Produksi testosteron dan DHT ditemukan lebih tinggi pada kulit pasien yang berjerawat. Androgen akan meningkatkan proliferasi sebosit utamanya sebosit pada wajah.
Tingginya kadar androgen pada pasien AV dewasa juga ditemukan pada penelitian yang dilakukan oleh Pochi dkk. pada pasien AVM dewasa yang resisten terhadap terapi memiliki hiperandrogenisme adrenal, hiperandrogenisme ovarium dan kadar estrogen yang rendah. $^{41}$ Studi lain menunjukkan adanya peningkatan kadar testosteron pada $90 \%$ perempuan yang menderita AV. Hal ini menjadi bukti bahwa pada AV terjadi abnormalitas produksi androgen. ${ }^{42}$

Hubungan antara kadar androgen dan perahan AV tidak selalu menunjukkan korelasi. Studi yang dilakukan oleh Levell dkk. menunjukkan terdapat hubungan yang lemah antara jumlah AV dengan kadar DHEAS perempuan usia kurang dari 25 tahun, namun hubungan dengan androgen lainnya tidak ditemukan. ${ }^{43}$ Penelitian yang dilakukan Cibula dkk. menunjukkan bahwa derajat keparahan AV tidak berhubungan dengan tanda klinis dan laboratoris adanya hiperandrogenemia. ${ }^{44}$ Hal ini menjadi dasar bahwa keparahan AV dapat ditentukan oleh hipersentivitas organ akhir terhadap kadar androgen yang bersirkulasi. Pada penelitian ini 50\% perempuan memiliki Policystic Ovary Syndrome (PCOS) yang merupakan penyebab tersering hiperandrogenisme pada perempuan.

Di dalam folikel rambut terdapat enzim yang dapat mengkoversi androstendion menjadi testosteron, yaitu enzim 17 $\beta$-HSD. Testosteron dapat dikonversi menjadi DHT yang lebih poten oleh enzim $5 \alpha$-reduktase. Kadar serum androgen kemungkinan berhubungan dengan AV melalui aksi secara langsungnya pada kelenjar sebasea untuk menstimulus enzim lokal. Pada pasien kelompok AV kedua enzim ini mengalami peningkatan meskipun tidak berbeda secara signifikan. ${ }^{45}$ 


\section{Sebum}

Sebum diproduksi oleh kelenjar sebasea yang merupakan kelenjar holokrin. Kelenjar ini tidak ditemukan pada telapak tangan, telapak kaki dan dorsum pedis. Sebum terdiri dari trigliserida, asam lemak, wax ester, squalene, ester kolesterol dan kolesterol. ${ }^{46-49}$ Fungsi dari sebum adalah melubrikasi kulit untuk memberikan kelembaban, memudahkan transpor antioksidan ke dalam kulit, memiliki aktivitas antibakterial dan fungsi anti dan pro inflamasi, dan juga membantu proses penyembuhan. ${ }^{50}$

Sebum memiliki peranan dalam patogenesis akne melalui sekresinya yang meningkat, perubahan komposisi lipid dan ratio oksidan/antioksidan. ${ }^{50}$ Ditemukan lipoperoksida di sebum yang merupakan hasil peroskidasi squalene dan kadar vitamin E yang menurun. ${ }^{27}$ Lipoperoksida akan memicu proliferasi keratinosit sementara peroksida akan mamanggil sitokin proinflamasi dan pengaktifan dari peroxisome proliferator-activated receptors (PPAR). ${ }^{27,}{ }^{51}$ Kerja sebosit diregulai oleh androgen, estrogen, ligan PPAR, neuropeptide, liver-X receptor ligands (LXR), histamin, retinoid dan vitamin D. ${ }^{52}$

\section{GAMBARAN KLINIS}

AV lebih sering mengenai daerah wajah dibandingkan dada, punggung dan bahu. Lesi dapat bersifat non inflamasi seperti komedo terbuka dan komedo tertutup serta lesi inflamasi berupa papul, pustul, dan nodul. Komedo terbuka lebih mudah divisualisasi dibandingkan komedo tertutup karena komedo terbuka berupa warna gelap yang merupakan tumpukan keratin dan lipid sementara komedo tertutup lebih pucat dan lesi dapat dilihat dengan menarik kulit. Lesi inflamasi berwarna merah dengan ostium yang lebih besar, lesi berfluktuasi dan nyeri.
Nodul yang besar disebut kista dan menggambarkan kasus AV yang berat. ${ }^{16}$

AV dewasa dibedakan menjadi dua jenis: ${ }^{6}$

1. AVM adalah AV sejak remaja dan masih muncul sampai usia dewasa dan pertengahan. Lesi muncul sepanjang waktu dan bertambah banyak saat menjelang haid.

2. AV awitan lambat adalah akne yang muncul pertama kali setelah pubertas. Akne jenis ini dapat dibagi menjadi:

a. Akne dagu, yaitu akne inflamasi pada perempuan dewasa yang bertambah banyak menjelang haid utamanya di daerah dagu dan perioral.

b. Akne sporadik, yaitu akne yang muncul saat usia lanjut yang dihubungkan dengan penyakit sistemik.

Lesi AVM biasanya berlokasi di daerah sepertiga wajah bawah, garis dagu dan leher. Keterlibatan bahu dan punggung dapat ditemukan, dan terdapat lesi komedo di bagian dahi namun tidak selalu menonjol. ${ }^{6}$

AV awitan lambat biasanya kemunculannya tidak dapat diprediksi dan bersama dengan penyakit sistemik lainnya. Akne bisanya ada pada satu lokasi berupa lesi papul dan pustul dengan komedo yang sedikit. Pada pasien usia $>60$ tahun, akne sering terlihat di daerah tubuh. $^{54}$

Berbeda dengan AV remaja, AV dewasa biasanya muncul secara bertahap dengan keparahan ringan sampai sedang. Sementara, AV remaja muncul cepat dan parah. ${ }^{55,56} \mathrm{AV}$ dewasa memiliki dua profil klinis yaitu: ${ }^{56}$ (1) lesi non inflamasi dengan hiperseborea terdapat banyak komedo tertutup dan jarang komedo terbuka, (2) lesi inflamasi dengan keparahan ringan hingga sedang, nodus dan kista berada pada bagian sepertiga wajah bawah, garis rahang dan leher (akne dagu). 


\section{Derajat keparahan AV}

Derajat keparahan AV dapat diklasifikasikan menjadi AV ringan (AVR), AV sedang (AVS) dan AV berat (AVB) (tabel 4). ${ }^{57}$ Sedangkan berdasarkan usia, AV diklasifikasikan sebagai AV remaja dan AV dewasa. dengan antibiotik topikal pada lesi akne campuran atau inflamasi.

Pada pasien inflamasi utamanya pasien perempuan dewasa dapson topikal gel 5\% direkomendasikan. Asam azelat dapat digunakan sebagai terapi tambahan dan direkomendasikan pada kasus dispigmentasi pasca inflamasi.

Rekomendasi antibiotik sistemik ${ }^{1}$

Penggunaan antibiotik sistemik direkomedasikan pada kasus AVS dan AVB dan akne inflamasi yang resisten terhadap

\begin{tabular}{|c|c|}
\hline Klasifikasi & dan akne inflamasi yang resisten terhadap \\
\hline Akne vulgaris ringan & 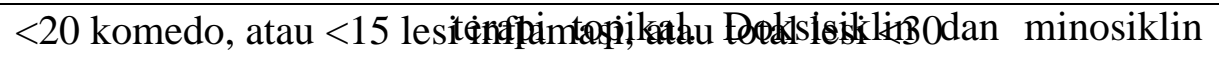 \\
\hline Akne vulgaris sedang & 20-100 komedo, atau 15-5lelbibi irfektifsi, bitau tditalinelinglah25 dengan \\
\hline Akne vulgaris berat & 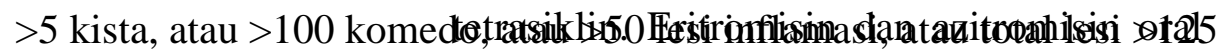 \\
\hline
\end{tabular}

\section{PENATALAKSANAAN}

Prisip tatalaksana AV sesuai dengan 4 tahapan patofisiologinya yaitu: ${ }^{58}$

1. Mengurangi hiperproliferasi keratinosit folikular

2. Menurunkan aktivitas kelenjar sebasea

3. Mengurangi populasi bakteri folikel, utamanya $P$. Acnes

4. Memunculkan efek antiinflamasi

Rekomendasi terapi topikal $^{1}$

Monoterapi AVR yang direkoemdasikan adalah penggunaan Benzoil peroksida (BPO) atau dikombinasikan dengan eritromisin atau klindamisin topikal. Sementara terapi AVS dan AVB dapat ditambahkan retinoid topikal atau antibiotik sistemik. BPO dapat mencegah resistensi bakteri sehingga direkomendasikan untuk diberikan pada pasien yang mendapat terapi antibiotik topikal atau sistemik.

Antibiotik topikal tidak direkomendasikan sebagai monoterapi karena risiko resistensi yang ditimbulkan. Retinoid topikal direkomendasikan untuk monoterapi kasus akne komedonal atau dikombinasikan efektif dalam mengatasi akne, namun penggunaannya harus berhati-hati pada pasien perempuan hamil dan anak usia $<8$ tahun. Sebaiknya penggunaan antibiotik dilakukan dalam durasi sependek mungkin dan dilakukan evaluasi ulang pada bulan ke 3 - 4 untuk meminimaisir kejadian resistensi. Tidak direkomendasikan untuk menggunakan monoterapi antibiotik sistemik.

Rekomendasi penggunaan bahan hormon ${ }^{1}$ Pemberian kontrasepsi oral yang mengandung estrogen direkomendasikan untuk terapi akne inflamasi pada perempuan. Spironolakton juga efektif sebagai terapi akne perempuan. Pasien dengan akne inflamasi berat dapat diberikan kortikosteroid oral saat memulai terapi akne standar. Pasien dengan riwayat hiperandrogenisme, penggunaan kortikosteroid dosis rendah dapat direkomendasikan sebagai terapi akne.

Rekomendasi untuk isotretinoin ${ }^{1}$

Isotretinoin oral direkomendasikan untuk terapi AVB. Selain itu isotretinon dapat 
diberikan pada AV sedang yang resisten terhadap terapi atau untuk terapi akne dengan komplikasi skar atau distress psikososial. Penggunaan isotertinoin dosis rendah pada tatalaksana akne daapt mengurangi frekuensi dan efek samping obat. Perlu dilakukan pemantau terhadap fungsi hati, kadar kolesterol dan trigliserida pada pasien yang mendapat terapi ini.

\section{PENUTUP}

Munculnya akne dewasa dapat dipengaruhi oleh faktor hormonal, genetik, penggunaan kosmetik, resistensi $P$. acnes terhadap penggunaan antibiotik dan paparan sinar matahari. Telah banyak penelitian yang menunjukkan peran hormon androgen dalam patogenesis akne yaitu melalui produksi hormon androgen sistemik, lokal dan sensitivitas dari reseptor androgen di kulit. Tatalaksana pasien AV dewasa didasarkan dari derajat keparahan akne yang diderita. 
Tabel 5. Algoritma tatalaksana $\mathrm{AV}^{59}$

\begin{tabular}{|c|c|c|c|c|c|}
\hline & \multirow{2}{*}{$\begin{array}{l}\text { Ringan } \\
\text { Komedo }\end{array}$} & \multicolumn{2}{|c|}{ Sedang } & \multicolumn{2}{|l|}{ Berat } \\
\hline & & Papul/Pustul & Papul/pustul & Nodus & Konglobata / fulminan \\
\hline Pertama & Retinoid topikal & $\begin{array}{l}\text { Retinoid topikal }+ \\
\text { antimikroba topikal }\end{array}$ & $\begin{array}{l}\text { Antibiotik oral }+ \text { retinoid } \\
\text { topikal } \pm \text { BPO }\end{array}$ & $\begin{array}{l}\text { Antibiotik oral + retinoid topikal } \\
\pm \mathrm{BPO}\end{array}$ & $\begin{array}{l}\text { Isotretionin oral } \pm \text { kortikosteroid } \\
\text { oral }\end{array}$ \\
\hline Kedua & $\begin{array}{l}\text { Asam azelat atau asam } \\
\text { salisilat }\end{array}$ & $\begin{array}{l}\text { Asam azelat atau } \\
\text { asam salisilat }\end{array}$ & $\begin{array}{l}\text { Antibiotik oral }+ \text { retinoid } \\
\text { topikal } \pm \text { BPO }\end{array}$ & $\begin{array}{l}\text { Isotretinoin oral atau antibiotik } \\
\text { oral }+ \text { retinoid topikal } \pm \text { BPO / } \\
\text { asam azelat }\end{array}$ & Antibiotik oral dosis tinggi $+\mathrm{BPO}$ \\
\hline Perempuan & - & - & $\begin{array}{l}+ \text { kontrasepsi oral / anti } \\
\text { androgen }\end{array}$ & $\begin{array}{l}+ \text { kontrasepsi oral / anti } \\
\text { androgen }\end{array}$ & +kotrasepsi oral / anti androgen \\
\hline Pilihan invasif & Ektraksi komedo & - & Ektraksi komedo & $\begin{array}{l}\text { Ekstraksi komedo, } \\
\text { kortikosteroid intra lesi }\end{array}$ & Kortikosteroid intra lesi \\
\hline $\begin{array}{l}\text { Terapi } \\
\text { refraktori }\end{array}$ & Periksa kepatuhan pasien & $\begin{array}{l}\mathrm{P} \\
\mathrm{E} \\
\mathrm{P} \\
\mathrm{kc} \\
\mathrm{L}\end{array}$ & $\begin{array}{l}\text { riksa kepatuhan pasien } \\
\text { slusikan folikulitis akbiat ba } \\
\text { rempuan: eksklusi PCOS, } \\
\text { ngenital } \\
\text { ki-laki: eksklusi hiperplasia }\end{array}$ & $\begin{array}{l}\text { teri gram negatif } \\
\text { tumor adrenal dan ovarium, hip } \\
\text { drenal kongenital }\end{array}$ & erplasia adrenal \\
\hline Maintenance & $\begin{array}{l}\text { Topikal retinoid } \\
\pm \mathrm{BPO}\end{array}$ & & & & \\
\hline
\end{tabular}




\section{DAFTAR PUSTAKA}

1. Zaenglein AL, Pathy AL, Schlosser BJ, Alikhan A, Baldwin HE, Berson DS, et al. Guidelines of care for the management of acne vulgaris. J Am Acad Dermatol. 2016;74(5):945-73 e33.

2. Bhate K, Williams HC. Epidemiology of acne vulgaris. $\mathrm{Br} J$ Dermatol. 2013;168(3):474-85.

3. Collier CN, Harper JC, Cafardi JA, Cantrell WC, Wang W, Foster KW, et al. The prevalence of acne in adults 20 years and older. J Am Acad Dermatol. 2008;58(1):56-9.

4. Schmitt JV, Masuda PY, Miot HA. [Acne in women: clinical patterns in different age-groups]. An Bras Dermatol. 2009;84(4):349-54.

5. Holzmann R, Shakery K. Postadolescent acne in females. Skin Pharmacol Physiol. 2014;27 Suppl 1:3-8.

6. Williams C, Layton AM. Persistent acne in women : implications for the patient and for therapy. Am J Clin Dermatol. 2006;7(5):281-90.

7. Kokandi A. Evaluation of acne quality of life and clinical severity in acne female adults. Dermatol Res Pract. 2010;2010.

8. da Cunha MG, Fonseca FL, Machado $\mathrm{CD}$. Androgenic hormone profile of adult women with acne. Dermatology. 2013;226(2):167-71.

9. Schafer T, Nienhaus A, Vieluf D, Berger J, Ring J. Epidemiology of acne in the general population: the risk of smoking. Br J Dermatol. 2001;145(1):100-4.

10. Deplewski D, Rosenfield RL. Role of hormones in pilosebaceous unit development. Endocr Rev. 2000;21(4):363-92.

11. Orentreich N, Brind JL, Rizer RL, Vogelman JH. Age changes and sex differences in serum dehydroepiandrosterone sulfate concentrations throughout adulthood. J Clin Endocrinol Metab. 1984;59(3):5515.

12. Whitehouse HJ, Fryatt E, El-Mansori I, Layton AM. . Oral antibiotics for acne: are we adopting premium use? Annual
Conference of the British Association of Dermatologists; Brimingham. Birmingham, U.K.2016.

13. Barbieri JS, Hoffstad O, Margolis DJ. Duration of oral tetracycline-class antibiotic therapy and use of topical retinoids for the treatment of acne among general practitioners (GP): A retrospective cohort study. J Am Acad Dermatol. 2016;75(6):1142-50 e1.

14. Kuet KH, Finch C, Fryatt E, al. e, editors. A decade later, has the prevalence of skin colonization by resistant propionibacteria increased in our patients with acne? . Annual Conference of the British Association of Dermatologists; 2015 7-9 July; Manchester. U.K.

15. Kligman AM. Post-adolescent acne in women. Cutis. 1992;48:75-7.

16. Thiboutot D, Gilliland K, Light J, Lookingbill D. Androgen metabolism in sebaceous glands from subjects with and without acne. Arch Dermatol. 1999;135(9):1041-5.

17. Eady EA, Cove JH, Holland KT, Cunliffe WJ. Erythromycin resistant propionibacteria in antibiotic treated acne patients: association with therapeutic failure. $\mathrm{Br} \mathrm{J}$ Dermatol. 1989;121(1):51-7.

18. Knaggs HE, Wood EJ, Rizer RL, Mills $\mathrm{OH}$. Post-adolescent acne. Int J Cosmet Sci. 2004;26(3):129-38.

19. Zaenglein LA, Thiboutot DM, Strauss JS. In. Acne Vulgaris and Acneiform Eruptions. In: Wolff K, Goldsmith LA, Katz SI, Gilchrest BA, Paller AS, Leffell DJ, editor. Fitzpatrick's Dermatology in General Medicine. 7 ed: McGraw-Hill; 2008.

20. Sitohang IBS. Patogenesis terkini Akne Vulgaris. MDIV. 2011;38:149-52.

21. Bataille V, Snieder H, MacGregor AJ, Sasieni P, Spector TD. The influence of genetics and environmental factors in the pathogenesis of acne: a twin study of acne in women. J Invest Dermatol. 2002;119(6):1317-22.

22. Thiboutot DM, Knaggs H, Gilliland K, Hagari S. Activity of type 15 alphareductase is greater in the follicular 
infrainfundibulum compared with the epidermis. $\mathrm{Br} \quad \mathrm{J}$ Dermatol. 1997;136(2):166-71.

23. Thiboutot D, Knaggs H, Gilliland K, Lin G. Activity of 5-alpha-reductase and 17beta-hydroxysteroid dehydrogenase in the infrainfundibulum of subjects with and without acne vulgaris. Dermatology. 1998;196(1):38-42.

24. Thiboutot D. Regulation of human sebaceous glands. J Invest Dermatol. 2004;123(1):1-12.

25. Ganceviciene R, Graziene V, Fimmel S, Zouboulis CC. Involvement of the corticotropin-releasing hormone system in the pathogenesis of acne vulgaris. $\mathrm{Br} \mathrm{J}$ Dermatol. 2009;160(2):345-52.

26. Melnik B, Schmitz G. FGFR2 signaling and the pathogenesis of acne. J Dtsch Dermatol Ges. 2008;6(9):721-8.

27. Ottaviani M, Alestas T, Flori E, Mastrofrancesco A, Zouboulis CC, Picardo M. Peroxidated squalene induces the production of inflammatory mediators in $\mathrm{HaCaT}$ keratinocytes: a possible role in acne vulgaris. $J$ Invest Dermatol. 2006;126(11):2430-7.

28. Prough RA, Clark BJ, Klinge CM. Novel mechanisms for DHEA action. J Mol Endocrinol. 2016;56(3):R139-55.

29. Maggio M, De Vita F, Fisichella A, Colizzi E, Provenzano S, Lauretani F, et al. DHEA and cognitive function in the elderly. J Steroid Biochem Mol Biol. 2015;145:281-92.

30. Labrie F. DHEA, important source of sex steroids in men and even more in women. Prog Brain Res. 2010;182:97-148.

31. Labrie F, Luu-The V, Belanger A, Lin SX, Simard J, Pelletier G, et al. Is dehydroepiandrosterone a hormone? J Endocrinol. 2005;187(2):169-96.

32. Vandenput L, Ohlsson C. Genome-wide association studies on serum sex steroid levels. Mol Cell Endocrinol. 2014;382(1):758-66.

33. Hammer FSS, Lux P, Maser-Gluth C, Stewart PM, Allolio B, Arlt W. No evidence for hepatic conversion of dehydroepiandrosterone (DHEA) sulfate to DHEA: in vivo and in vitro studies.
Journal of Clinical Endocrinology and Metabolism. 2005;90:3600-5.

34. Stanczyk FZ. Diagnosis of hyperandrogenism: biochemical criteria. Best Pract Res Clin Endocrinol Metab. 2006;20(2):177-91.

35. Kushnir MM, Blamires T, Rockwood AL, Roberts WL, Yue B, Erdogan E, et al. Liquid chromatography-tandem mass spectrometry assay for androstenedione, dehydroepiandrosterone, and testosterone with pediatric and adult reference intervals. Clin Chem. 2010;56(7):1138-47.

36. Labrie F, Luu-The V, Labrie C, Pelletier G, El-Alfy M. Intracrinology and the skin. Horm Res. 2000;54(5-6):218-29.

37. Uemura M, Tamura K, Chung S, Honma S, Okuyama A, Nakamura Y, et al. Novel 5 alpha-steroid reductase (SRD5A3, type-3) is overexpressed in hormonerefractory prostate cancer. Cancer Sci. 2008;99(1):81-6.

38. Ebede TL, Arch EL, Berson D. Hormonal treatment of acne in women. $\mathrm{J}$ Clin Aesthet Dermatol. 2009;2(12):1622.

39. Thiboutot D, Chen W. Update and future of hormonal therapy in acne. Dermatology. 2003;206(1):57-67.

40. Cappel M, Mauger D, Thiboutot D. Correlation between serum levels of insulin-like growth factor 1 , dehydroepiandrosterone sulfate, and dihydrotestosterone and acne lesion counts in adult women. Arch Dermatol. 2005;141(3):333-8.

41. Pochi PE, Longcope C. Adrenocortical response to exogenous ACTH in women with chronic, treatment resistant acne. J Invest Dermatol. 1984;82:412.

42. Seirafi H, Farnaghi F, VasheghaniFarahani A, Alirezaie NS, Esfahanian F, Firooz A, et al. Assessment of androgens in women with adult-onset acne. Int $\mathbf{J}$ Dermatol. 2007;46(11):1188-91.

43. Odlind V, Carlstrom K, Michaelsson G, Vahlqvist A, Victor A, Mellbin $\mathrm{T}$. Plasma androgenic activity in women with acne vulgaris and in healthy girls 
before, during and after puberty. Clin Endocrinol (Oxf). 1982;16(3):243-9.

44. Cibula D, Hill M, Vohradnikova O, Kuzel D, Fanta M, Zivny J. The role of androgens in determining acne severity in adult women. $\mathrm{Br} \mathrm{J}$ Dermatol. 2000;143(2):399-404.

45. Thiboutot D, Martin P, Volikos L, et al. Oxidative activity of the type 2 isozyme of 17B-Hydroxysteroid dehydrogenase (17B-HSD) predominates in human sebaceous glands. J Invest Dermatol. 1998;111:390-5.

46. Downing DT, Stewart ME, Wertz PW, Colton SW, Abraham W, Strauss JS. Skin lipids: an update. J Invest Dermatol. 1987;88(3 Suppl):2s-6s.

47. Thody AJ, Shuster S. Control and function of sebaceous glands. Physiol Rev. 1989;69(2):383-416.

48. Nikkari T, Schreibman PH, Ahrens EH, Jr. In vivo studies of sterol and squalene secretion by human skin. J Lipid Res. 1974;15(6):563-73.

49. Ramasastry P, Downing DT, Pochi PE,

Strauss JS. Chemical composition of human skin surface lipids from birth to puberty. J

Invest Dermatol. 1970;54(2):139-44.

50. Zouboulis CC. Acne and sebaceous gland function. Clin Dermatol. 2004;22(5):360-6.

51. Smith RN, Braue A, Varigos GA, Mann NJ. The effect of a low glycemic load diet on acne vulgaris and the fatty acid composition of skin surface triglycerides. J Dermatol Sci. 2008;50(1):41-52.

52. Zouboulis CC, Schagen S, Alestas T. The sebocyte culture: a model to study the pathophysiology of the sebaceous gland in sebostasis, seborrhoea and acne. Arch Dermatol Res. 2008;300(8):397-413.

53. Youn SW, Na JI, Choi SY, Huh CH, Park KC. Regional and seasonal variations in facial sebum secretions: a proposal for the definition of combination skin type. Skin Res Technol. 2005;11(3):189-95.

54. Marks R. Acne and its management beyond the age of 35 years. Am J Clin Dermatol. 2004;5(6):459-62.
55. Holzmann R, Shakery K. Postadolescent acne in females. Skin Pharmacol Physiol. 2014;27 Suppl 1:3-8.

56. Preneau S, Dreno B. Female acne - a different subtype of teenager acne? J Eur Acad Dermatol Venereol. 2012;26(3):277-82.

57. Lehmann HP, Robinson KA, Andrews JS, Holloway V, Goodman SN. Acne therapy: a methodologic review. J Am Acad Dermatol. 2002;47(2):231-40.

58. Zaenglein LA, Thiboutot DM, Strauss JS. In. Acne Vulgaris and Acneiform Eruptions. In: Wolff K, Goldsmith LA, Katz SI, Gilchrest BA, Paller AS, Leffell DJ, editor. Fitzpatrick's Dermatology in General Medicine. 7 ed: McGraw-Hill; 2008.

59. Gollnick H, Cunliffe W, Berson D, Dreno B, Finlay A, Leyden JJ, et al. Management of acne: a report from a Global Alliance to Improve Outcomes in Acne. J Am Acad Dermatol. 2003;49(1 Suppl):S1-37. 